\title{
Digital Commons @ Ryerson
}

RYERSON'S INSTITUTIONAL REPOSITORY 


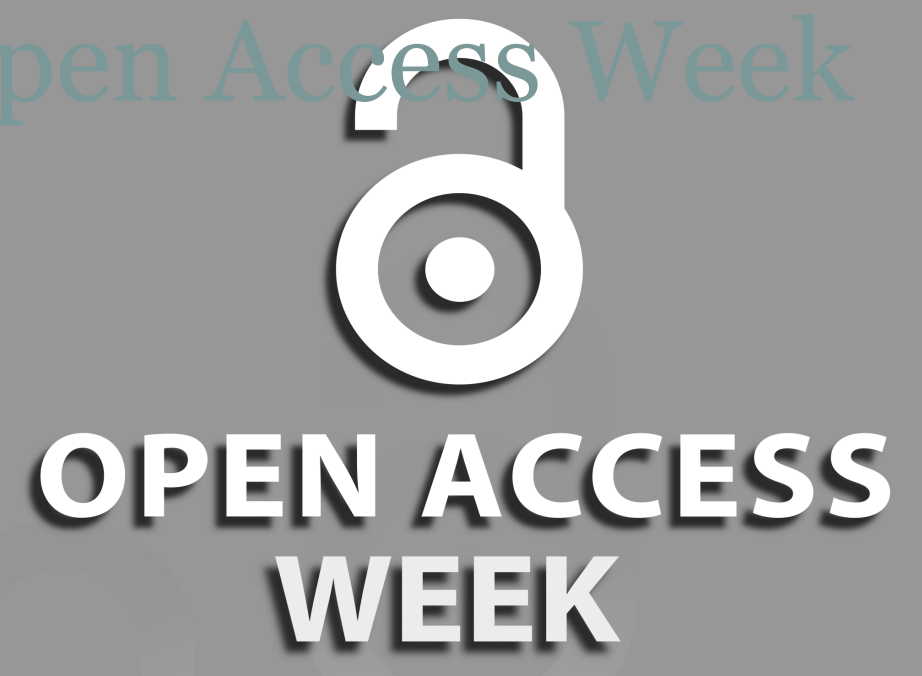

October 19-23, 2009 openaccessweek.org 


\section{What is Open Access}

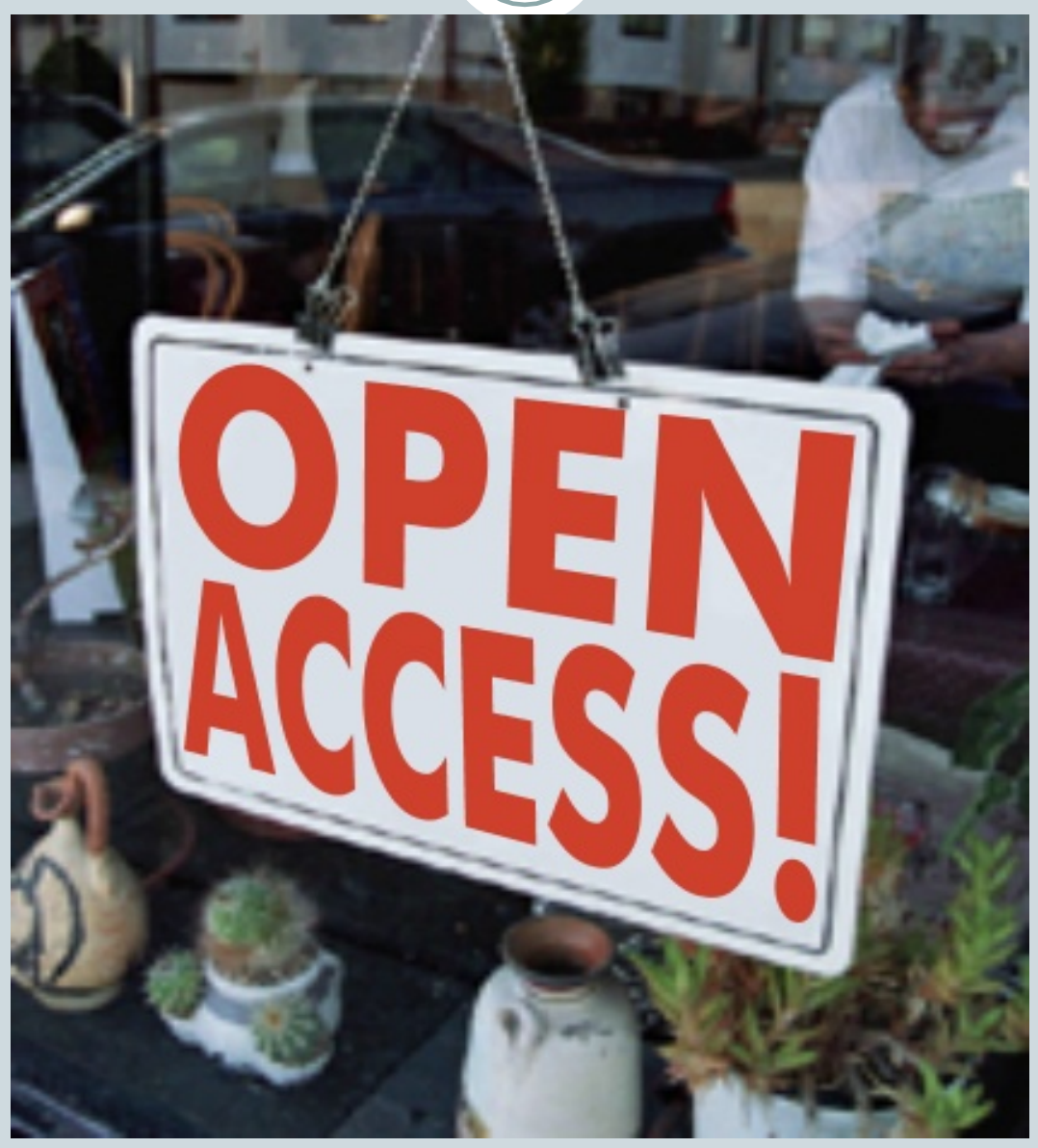

$\underline{\text { Open Access (Store Front) by Gideon Burton }}$ 


\section{Subversive Proposal}

$(())$

\section{American News}

SCIENCE

\section{DARWINISM}

\section{AND THE INTERNET}

Why scientific journals could go the way of the pterodactyl

S.

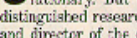

and dinester of the
nitive siences center
Britain's Lniversity

Southampton sidmits
uring the virtual oser-
throw of one of gcienct

most cherished institu-
tions: print journals.

With Internes usage ex-

groxing legion of scien-
tists say the venerable

scientife journsla are

urging seientsts to pcest

research papeer electiven-
ically first, and coly then

It's a radical notion that is being ad-
vanced it conferenees and, $\alpha$ course,

vanced at conferences snd, of course
on the Net. If it succeeds, it conid tiras

matically chenge-and perhaps weak-

en--he traditional process by which
relereed rerodicas ver research and

stape entire fields af science.
on cuaro. Not surymisingly, the pubisis.

ON cuaro. Not suryminingly, the pubilica-
tima aneady are pulling up the draw-

New England Jourrat of thedicine wi

same rales to Internet that apply to

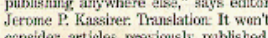

incluiling on the Imemet.

ment of electroric yublshing is rocking

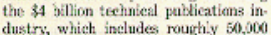

petain their prestige and firanchlises, yet

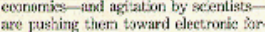

muts. "Costs are ap, wostage is 4 pat, and

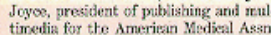

"You ean't grow enough new revenue

as the future."

30 gusiness wEEK / June 26. 1995

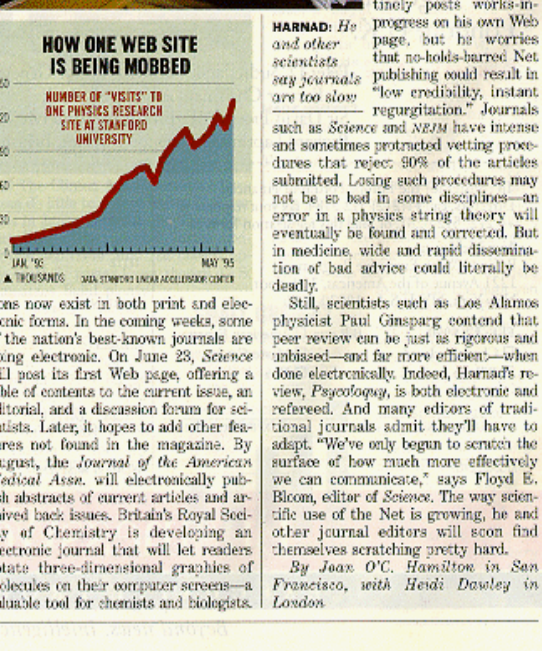

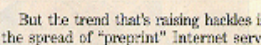
ens-there are atoont 70 up so tar $\rightarrow$.

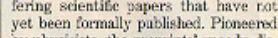

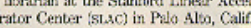

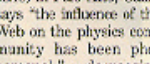

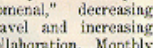

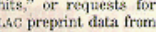

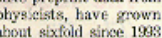

gum strers. What wor. ries some scientists is
ho poxentin in the pute

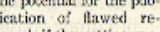

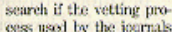

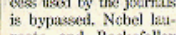
reate and Rookecereler

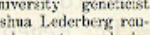

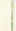
e and be and 


\section{What you need to Know}

- Mandates

- Copyright

- Author Rights

- Research Impact 


\section{Mandates}

- Canadian Breast Cancer Research Alliance

- Genome Canada

- Ontario Institute for Cancer Research

- Canadian Cancer Society

- National Cancer Institute of Canada

- Canadian Health Services Research Foundation

- Canadian Institutes of Health Research

- Michael Smith Foundation for Health Research

- Fonds de la recherche en sante Quebec

- National Research Council of Canada 


\section{Other Mandates}

Some Institutional Mandates

- Athabasca

- Queen's (thesis mandate)

- University of Calgary: Library and Cultural Resources

Some International Mandates

- National Institutes of Health

- Wellcome Trust

- CERN 


\section{Copyright}

91\% of publishers permit some form of self-archiving

\section{SHERPA/RoMEO}

\section{ROMEO colour Archiving policy}

green

blue

yellow

white can archive pre-print and post-print or publisher's version/PDF

can archive post-print (ie final draft post-refereeing) or publisher's version/PDF can archive pre-print (ie pre-refereeing)

archiving not formally supported 


\section{Author Rights}

- Notwithstanding any terms in the Publication Agreement to the contrary, AUTHOR and PUBLISHER agree as follows: 1 . Author's Retention of Rights. In addition to any rights under copyright retained by Author in the Publication Agreement, Author retains the right to (i) reproduce the Article in any material form for noncommercial purposes; (ii) to perform the Article in public for non-commercial purposes; (iii) to convert the Article by preparing derivative works; (iv) to make a sound recording, cinematographic film or other contrivance by means of which the Article may be mechanically reproduced or performed for non-commercial purposes; (v) to reproduce, adapt and publicly present the Article as a cinematographic film for non-commercial purposes; (vi) to communicate the work to the public by telecommunication for non-commercial purposes; and (vii) to authorize others to make any non-commercial use of the Article so long as Author receives credit as author and the journal in which the Article has been published is cited as the source of first publication of the Article. For example, Author may make and distribute copies in the course of teaching and research and may post the Article on personal or institutional Web sites and in other open access digital repositories.

- SPARC Canada author addendum 


\section{Research Impact}

- Open access articles attract up to $336 \%$ more citations 


\section{Digital Commons}

O

\section{Digital Commons@ @yerson}

